\title{
Do rádio à televisão: o personagem negro frente à mídia em dois filmes brasileiros ${ }^{1}$
}

Arthur Autran ${ }^{2}$

UFSCar

1. Uma versão deste texto foi apresentada no XIX Encontro da Compós (Associação Nacional dos Programas de Pós-Graduação), ocorrido na PUC (Pontifícia Universidade Católica) do Rio de Janeiro em junho de 2010. Agradeço ao prof. dr. Renato Pucci, que foi o comentador do trabalho nesse evento científico.

2. Professor doutor na Universidade Federal de São Carlos (UFSCar). 


\section{Resumo}

Este trabalho aborda dois filmes brasileiros, Rio, zona Norte (Nelson Pereira dos Santos, 1957) e Orfeu (Carlos Diegues, 1999), possuindo como foco da sua análise a forma como essas obras representam o afrodescendente. Deve-se considerar que ambos os filmes têm negros como personagens centrais (o elenco, de forma geral, também é dominado por atores e atrizes afrobrasileiros) e trazem como tema a vida do compositor popular que vive nos morros cariocas. Entretanto, Rio, zona Norte fala da vida do criador musical não incorporado pela indústria cultural brasileira, que ainda se encontrava na fase de ouro do rádio; já a trama de Orfeu gira em torno de um artista que tem relações com a grande mídia em plena era das corporações televisivas.

\section{Palavras-chave}

cinema brasileiro, representação do negro, indústria cultural

\section{Abstract}

This paper analyzes two Brazilian movies, Rio, zona Norte (Nelson Pereira dos Santos, 1957) and Orfeu (Carlos Diegues, 1999), focusing on the way these works portray Afro-descendant people. It must be considered that both movies have black people as their main characters, and the cast is also composed of Afro-Brazilian actors and actresses; in addition, these films take the lives of popular composers who live in the Rio de Janeiro's "favelas" as one of their themes. However, Rio, zona Norte's theme is the life of musical creators not incorporated by the Brazilian cultural industry, which was still in the golden phase of radio period; Orfeu's plot, nonetheless, addresses an artist who has relationships with the big media right in the middle of the television corporation's era.

\section{Key-words}

Brazilian cinema, African descendant in motion pictures, cultural industry 
Este texto tem como objetivo analisar a representação do afrobrasileiro, enfocando dois filmes compromissados com o discurso nacional popular: Rio, zona Norte (Nelson Pereira dos Santos, 1957) e Orfeu (Carlos Diegues, 1999).

As obras foram realizadas por diretores que integraram o Cinema Novo. Entretanto, observa-se que Rio, zona Norte foi feito antes de o movimento eclodir, no início dos anos 1960, enquanto Orfeu foi produzido bem depois do final do Cinema Novo. Essa distância temporal permitirá comparar as mudanças e as continuidades no discurso sobre o negro construído por uma fração representativa da modernidade cinematográfica entre nós, aquela ligada por origem ou por herança ao Cinema Novo.

Para Ismail Xavier, o cinema brasileiro moderno é caracterizado pelo diálogo estético com movimentos de vanguarda, tais como a Nouvelle Vague, e outros cinemas novos, pela crítica às formas tradicionais da indústria cinematográfica e pela centralidade da "questão nacional" e da representação do povo, entre outros elementos. Segundo o ensaísta:

Em sua variedade de estilos e inspirações, o cinema moderno brasileiro acertou o passo do país com os movimentos de ponta de seu tempo. Foi um produto de cinéfilos, jovens críticos e intelectuais que, ao conduzirem essa atualização estética, alteraram substancialmente o estatuto do cineasta no interior da cultura brasileira, promovendo um diálogo mais fundo com a tradição literária e com os movimentos que marcaram a música popular e o teatro daquele momento (Xavier, 2001, p. 18). 
Rio, zona Norte pode ser integrado a essa definição de modernidade cinematográfica, pois se trata de uma fita realizada em um momento de grandes esperanças quanto à função do cinema na sociedade brasileira e à constituição de uma nova forma estética para expressar a nossa experiência cultural e social. Já Orfeu pertence a um momento de aparente esgotamento da experiência moderna e no qual há mesmo restrições de muitos em estabelecer relações mais profundas entre as experiências artísticas e o mundo social.

No entanto, nem tudo é diferença entre os dois filmes. Boa parte dos atores (incluindo os principais) são negros. Ambos têm como espaço diegético dominante a favela carioca, na qual vivem os personagens centrais, e, tanto em um caso como no outro, tais personagens têm uma relação positiva com a comunidade. Mais ainda do que isto: tanto Espírito da Luz Soares - personagem principal de Rio, zona Norte - quanto o personagem-título Orfeu são compositores que expressam nas suas músicas as experiências, as alegrias, as aflições e os questionamentos das pessoas do morro. Finalmente, ambos os filmes apresentam a questão da mediação da produção artística popular pela indústria cultural.

\section{Preâmbulo literário: a centralidade de Jorge Amado}

Antes de analisar Rio, zona Norte e Orfeu, é fundamental ressaltar que a obra de Jorge Amado exerceu influência sobre certa fração do cinema brasileiro. É possível afirmar isso com base tanto nas numerosas adaptações empreendidas em filmes ${ }^{3}$ quanto na forma pela qual o afrodescendente é representado, ou seja, como ator da sua própria história e, ao mesmo tempo, símbolo de todo o povo brasileiro.

Em romances como Jubiabá (1935), Mar morto (1936), Capitães da areia (1937) e Tenda dos milagres (1970), entre outros, Jorge Amado fixou personagens negros ou mulatos no centro da narrativa, a qual também possui uma série de referências ao universo afrobrasileiro, especialmente no que diz respeito à religião, à culinária, à música e à capoeira.

Romance de importância capital é Jubiabá, que narra a história aventurosa de Antônio Balduíno, apelidado de Baldo. Trata-se de um negro nascido e criado na cidade de Salvador e que tem a vida
3. Dentre outras, destacam-se as seguintes adaptações das obras de Jorge Amado para o cinema: Terra violenta (Eddie Bernoudy, 1948), Seara vermelha (Alberto D'Aversa, 1963), Dona Flor e seus dois maridos (Bruno Barreto, 1976), Tenda dos milagres (Nelson Pereira do Santos, 1977), Jubiabá (Nelson Pereira dos Santos, 1987), Tieta do agreste (Carlos Diegues, 1996) e Capitães de areia (Cecília Amado, 2011). Ademais, há documentários sobre Jorge Amado, tais como o curta-metragem Na casa de Rio Vermelho (David Neves e Fernando Sabino, 1974) e o média-metragem Jorjamado no cinema (Glauber Rocha, 1977). 
marcada pela extrema pobreza. Após viver a infância em um morro, Baldo vai viver como empregado na casa de uma família de posses, na qual é bem tratado e ainda conhece Lindinalva, filha dos donos da casa, moça ruiva e sardenta que se torna sua companheira de brincadeiras. Mas ele é expulso da casa, pois todos acreditam que Antônio Balduíno espiava o corpo de Lindinalva. A partir de então, Baldo pensa sempre nela quando faz sexo com uma mulher e, ao mesmo tempo, passa a odiar os brancos. Torna-se mendigo e vagabundo, mas consegue fazer boa carreira como boxeador, até que é derrotado em uma luta, na qual estava completamente bêbado pois soubera que Lindinalva ficara noiva, e isso o transtornou. Após viajar muito pelo interior, volta a Salvador e termina por descobrir que Lindinalva estava morrendo. Após o falecimento dela, ele cuida do filho branco da amada. Para sustentar o menino, tem de trabalhar duro na estiva, mas é somente aí que ganha consciência política, pois participa ativamente de uma greve que paralisa grande parte dos trabalhadores da cidade. Toda essa saga de Antônio Balduíno é cercada pelas várias mulheres com quem ele se relaciona, pela sua coragem nas brigas, pelo seu talento para fazer versos populares - que são vendidos a um poeta - e, especialmente, pela ligação com a religião afrobrasileira por meio de pai Jubiabá (pai de santo presente ao longo de toda a vida de Baldo, apoiando-o, dando-lhe conselhos e contando-lhe histórias de resistência dos negros, tais como a de Zumbi dos Palmares).

Para o contexto no qual foi escrito - meados da década de 1930 -, o romance Jubiabá tem como mérito incontestável o fato de colocar como herói principal um homem negro do povo, até então uma raridade nas artes brasileiras. Além disso, a cultura de origem africana surge com grande positividade em toda a obra.

Entretanto, Jubiabá incorre no "populismo literário", característica da obra do escritor Jorge Amado observada pelo crítico Alfredo Bosi (1994, p. 406). No romance em tela, essa característica se expressa na excessiva simplificação da oposição da luta de classes, especialmente na greve narrada ao final do romance. Ademais, a vida de Baldo como mendigo e marginal possui tons bastante romantizados.

Outro dado problemático em Jubiabá, como apontou David Brookshaw, é que o personagem Antônio Balduíno incorre no mito do negro sexualmente hiperativo, reforçando o estereótipo de ser humano mais ligado aos instintos do que à razão. Afigura-se ain- 
da mais estereotipada, em termos da construção, a personagem da mulata Rosenda Rosedá, uma das muitas amantes de Baldo (Brookshaw, 1983, p. 135-136).

Finalmente, como última limitação ideológica do romance de Jorge Amado, é possível apontar a total absorção da questão racial pela problemática da luta de classes. Se, de início, devido às injustiças sofridas e à influência de pai Jubiabá, Antônio Balduíno odeia todos os brancos, o desenlace da obra acaba por suprimir esse sentimento. A principal situação do final de Jubiabá, conforme mencionei, diz respeito a uma greve geral em Salvador ao longo da qual ele percebe que todos os trabalhadores são escravos, não havendo diferenças, para a luta proletária, entre brancos, negros ou amarelos.

A forma como o romance apresenta a questão do negro na sociedade brasileira acaba por explicá-la unicamente a partir do conflito de classes. Ou seja, não se reconhece qualquer especificidade na luta dos afrobrasileiros pelos seus direitos; ela é entendida apenas como extensão ou continuidade da luta do proletariado por melhores condições de vida e pelo fim do capitalismo. Conforme veremos, essa omissão da especificidade da luta do negro na sociedade brasileira também caracteriza Rio, zona Norte e Orfeu.

\section{Rio, zona Norte}

A influência de Jorge Amado no cinema se fez sentir mais claramente a partir dos anos 1950, em especial sobre os realizadores ligados ao Cinema Independente. A filmografia desse cinema é composta por um conjunto razoavelmente heterogêneo de obras, tais como Tudo azul (Moacyr Fenelon, 1951), Agulha no palheiro (Alex Viany, 1953), O saci (Rodolfo Nanni, 1953), Rio, 40 graus (Nelson Pereira dos Santos, 1955), Rio, zona Norte (Nelson Pereira dos Santos, 1957) e O grande momento (Roberto Santos, 1958).

O núcleo mais representativo em termos historiográficos composto pelas películas de Alex Viany, Nelson Pereira dos Santos e Roberto Santos - tem certa unidade temática, pois todos os filmes narram o cotidiano do povo brasileiro, com destaque para a favela e o subúrbio cariocas e a região proletária de São Paulo, dando atenção para os problemas dos setores populares, mas com um tom de dignidade e solidariedade. Alguns desses filmes também dialo- 
4. Os outros episódios foram dirigidos por Gillo Pontecorvo (Itália), Serguei

Guerassimov (União Soviética), Yannick Bellon (França) e Wu Kuo Yin (China). gam com o Neorrealismo cinematográfico italiano, especialmente os de Nelson Pereira dos Santos.

O grupo que constituiu o Cinema Independente foi formado basicamente por diretores e críticos que atuavam em São Paulo e no Rio de Janeiro e que eram ligados, via de regra, ao PCB (Partido Comunista Brasileiro), maior organização da esquerda brasileira de então e atuando na ilegalidade desde 1947. Dos componentes do grupo, podemos destacar: Nelson Pereira dos Santos, Alex Viany, Roberto Santos, Rodolfo Nanni, Carlos Ortiz e Ruy Santos, entre outros. Muito resumidamente, pode-se afirmar que o dado central na atuação ideológica do PCB era a assunção de que o Brasil se encontraria aguilhoado pela ação imperialista norte-americana, que explorava o país economicamente e o descaracterizava culturalmente; para libertar o país dessa situação, caberia às forças nacionalistas de esquerda, sob a égide do PCB, denunciar a dominação, lutar pelo desenvolvimento da indústria nacional, defender a nossa cultura e alinhar-se com outras nações exploradas e com os países socialistas capitaneados pela União Soviética.

Jorge Amado, desde os anos 1930, militou no PCB, tendo sido preso pela ditadura estadonovista em 1942. Em 1945, foi eleito deputado federal pelo PCB, no breve interregno de legalidade do partido no Brasil, tendo apresentado no ano seguinte um projeto de lei "que propunha a criação do CNC (Conselho Nacional de Cinema) e regulava normas de produção, importação, distribuição e exibição de filmes" (Simis, 1996, p. 138). Nos anos 1950, Jorge Amado gozava de uma posição central nas definições da política cultural do PCB (foi, inclusive, diretor da revista cultural Para Todos). Ademais, o escritor possuía ligações com a atividade cinematográfica, pois escreveu a história do longa-metragem Estrela da manhã (Jonald, 1950) e de Ana - episódio brasileiro dirigido por Alex Viany da produção da Alemanha Oriental intitulada A rosa dos ventos (Die windrose, 1957). ${ }^{4}$ Mas, para além dessa influência do PCB e de Jorge Amado, quais outras características eram comuns aos independentes? Maria Rita Galvão observa:

O que se chama na época de "cinema independente" é bastante complicado de entender e explicar. Fundamentalmente é o cinema feito pelos pequenos produtores, em oposição ao cinema das grandes empresas. Mas nem todo pequeno produtor é necessariamente "indepen- 
dente". Para ser qualificado de independente um filme deve ter um conjunto de características que frequentemente nada tem a ver com seu esquema de produção - tais como temática brasileira, visão crítica da sociedade, aproximação da realidade cotidiana do homem brasileiro. Misturam-se aos problemas de produção questões de arte e cultura, de técnica e linguagem, de criação autoral, e a "brasilidade" (Galvão, 1980, p. 14).

A oposição às grandes empresas (e aqui leia-se especialmente a Cia. Cinematogtráfica Vera Cruz) é um dado importante. Já no lançamento de Caiçara (Adolfo Celi, 1950), primeiro filme da produtora, Nelson Pereira dos Santos escreveu uma crítica na qual deplora o fato de a Vera Cruz entregar a distribuição dos seus filmes à Universal International, entendendo que tal associação impediria a produtora de realizar filmes com "caracterísiticas nacionais" (Santos, 1951).

Poucos anos depois da publicação dessa crítica, Nelson Pereira dos Santos dirigiu Rio, 40 graus (1955), obra deflagradora do moderno cinema brasileiro sob diversos aspectos: pela temática centrada na vida das pessoas pobres dos morros cariocas, pela inspiração formal no Neorrealismo italiano e pelo sistema de produção precário sem estúdios e equipamentos modernos, por exemplo - mas que, mesmo assim, permitiu a realização do filme.

Mas, para esse texto, interessa analisar o filme seguinte do realizador: Rio, zona Norte. O roteiro, escrito pelo próprio diretor, inspirava-se na vida do compositor Zé Keti, cuja produção musical, conforme Nelson Pereira dos Santos havia podido constatar, em boa parte se perdera por falta de alguma forma de registro mais perene (Fabris, 1994, p. 153).

A centralidade de Rio, zona Norte, para nossos fins, reside em três pontos: a) o personagem negro constitui-se com muito mais clareza do que em Rio, 40 graus, pois a ação dramática não se divide entre vários personagens, mas se concentra em um único, o compositor Espírito da Luz Soares; b) a cultura popular compõe o próprio cerne da narrativa, uma vez que toda ela gira em torno das tentativas de Espírito em ter as suas músicas gravadas e ser reconhecido como artista; c) a relação estabelecida no filme entre o artista popular, o artista intelectualizado de classe média e a mídia radiofônica.

O filme inicia-se com imagens do centro do Rio de Janeiro e 
da estação Central do Brasil. Logo após, há planos com o ponto de vista a partir de um trem em movimento e rapidamente já encontramos Espírito da Luz Soares (Grande Otelo) caído acidentalmente: ele está desacordado e ferido na linha do trem, sendo socorrido por transeuntes que vão chamar uma ambulância. A partir daí, se estabelece o procedimento narrativo recorrente de Rio, zona Norte: flashbacks da vida de Espírito como se fossem lembranças dele.

Em uma roda de samba no morro, Espírito conduz a música, interrompida por um homem ciumento que tenta ferir a cabrocha Adelaide (Malu). Felizmente, ninguém se fere, e o covarde é posto para fora. Ato contínuo, Espírito conhece Moacyr (Paulo Goulart), homem cujas vestes, gestos e tipo de fala denunciam seu pertencimento a outro universo social. Moacyr, que também é músico e para viver toca violino em orquestras, fica impressionado com o talento de Espírito, que passa a cantar várias músicas para ele. Na mesma mesa também está Maurício Silva (Jece Valadão), um “parceiro” de Espírito. Moacyr diz para Espírito procurá-lo, pois as obras do compositor popular seriam de grande qualidade. Ao final da noite, Espírito vai para o seu barraco e Adelaide, que o ouviu toda a noite, acompanha-o.

O despertar de Espírito após a noite de amor com Adelaide é carregado de um lirismo que nasce da forma como os hábitos cotidianos são mostrados, ou seja, pelo fluxo de tempo que respeita os pequenos atos, tais como levantar da cama para se vestir ou pentear o cabelo. É impossível não relacionar essas situações a outras do cotidiano, tal como as representadas por filmes neorrealistas: por exemplo, a famosa sequência na qual a empregada da pensão acorda e vai moer o café em Umberto D (Vittorio de Sica, 1952), mencionada por André Bazin como exemplo de um cinema em que a vida é "mostrada afinal como poesia” (1991, p. 298).

Adelaide vai imediatamente morar com Espírito. Os planos do casal descendo o morro são também carregados de significação poética, com enquadramentos que valorizam o conjunto da comunidade e a geografia íngreme do lugar. No entanto, quando Espírito vai avisar ao seu compadre Honório (Vargas Júnior) sobre a sua nova situação, encontra o filho Norival (Haroldo de Oliveira), adolescente que acabara de fugir de um reformatório. O pai acaba dando dinheiro para que o rapaz viaje a São Paulo. Espírito vai à emissora de rádio atrás de Moacyr, mas este não pode atendê-lo 
naquele momento. Lá mesmo, Espírito encontra Maurício, que diz ter conseguido um cantor interessado em gravar uma das músicas apresentadas na noite anterior: Alaor da Costa (Zé Keti). Mas este exige ser "parceiro" na composição para cantá-la. Ainda que contrariado, Espírito acaba concordando com a situação.

$\mathrm{Na}$ noite em que vários amigos do compositor se reúnem em torno do rádio para escutar a música, não apenas o ritmo ouvido é muito diferente do original como ainda o nome de Espírito não é citado entre os autores. Então, Espírito canta a música no ritmo que lhe parece o melhor e todos os amigos acompanham entusiasticamente, coisa que não ocorrera na execução da música no rádio. É importante observar que o tema da exploração do criador popular já estava presente em Jubiabá, pois Baldo vendia seus versos para um poeta, porém, ao contrário de Espírito, ele não se importava com o fato de sua obra se popularizar tendo outra pessoa reconhecida como o autor.

Espírito volta à emissora de rádio e lá encontra Maurício, que confirma que seu nome fora retirado da música - ele deveria se contentar com o valor que lhe seria pago. Precisando de dinheiro, Espírito acaba cedendo. Na mesma noite, descobre que Adelaide o deixou e ainda é atacado pelos comparsas de Norival, que estão atrás do rapaz para acertar contas. O filho de Espírito surge para defender o pai e acaba sendo assassinado pelos outros jovens. $\mathrm{Na}$ manhã seguinte, após o enterro, o inconsolável Espírito compõe uma música em homenagem ao filho e não aceita a nova "parceria" proposta por Maurício.

O compositor popular vai novamente à rádio e encontra a grande cantora Ângela Maria. Ela pede para escutar a música de Espírito, e ele, em um plano de meia figura, começa a cantar para ela. Enquanto o faz, surge em off a voz da cantora, que se sobrepõe à dele, demonstrando o entusiasmo dela com a obra. Ângela Maria promete cantar a música, mas pede para Espírito lhe levar a partitura. Ele vai à casa de Moacyr pedir para que ele faça a partitura. $\mathrm{O}$ apartamento está cheio de intelectuais e artistas, que inicialmente ouvem com atenção Espírito cantar sua composição, mas, depois, passam a fazer vários comentários esnobes. Então, eles começam a se entreter com uma amiga recém-chegada e literalmente dão as costas ao compositor. Espírito vai embora bastante sem jeito, mas Moacyr pede-lhe que volte no dia seguinte para escreverem a parti- 
tura. Espírito pega um trem lotado na Central do Brasil, ficando na porta, e começa a criar uma música. No entanto, alegre e distraído com sua própria criação, acaba caindo.

O flashback que apresenta a vida pregressa de Espírito termina aí. No seu decorrer, há interrupções, a fim de apresentar cenas como a chegada da ambulância, Espírito indo para a mesa de operações e o pessoal do hospital em busca de parentes. Mas as situações nas quais o flashback é interrompido têm também uma função central no projeto ideológico do filme: ao nível da diegese, as pessoas que o socorrem não sabem a identidade de Espírito e, em paralelo, vemos os papéis que estavam no seu bolso com suas letras perderem-se aos poucos. Isso até que um funcionário do hospital liga para Moacyr - cujo número de telefone é encontrado nas coisas do compositor - e afirma: "O senhor é a única pessoa que poderá dar indicações a respeito dele".

É justamente Moacyr quem vai ver o moribundo Espírito no hospital. Lá também está o compadre do compositor. Ambos veem Espírito morrer e, ao sair dali, Moacyr pergunta ao outro se conhece as músicas do artista popular. Ele responde que conhece, assim como outros moradores do morro, mas apenas as melhores.

É bem evidente que Espírito - até no nome - representa o povo brasileiro e sua cultura. Na perspectiva de Rio, zona Norte, ela é valiosa, mas não é reconhecida e ainda por cima é abastardada por oportunistas como Maurício e Alaor das Neves.

Rio, zona Norte, ao abordar a indústria cultural, transita entre a ingenuidade e a ambiguidade, pois, no filme de Nelson Pereira dos Santos, tudo se reduz à falta de caráter de algumas pessoas que trabalham na mídia radiofônica, encarnadas na diegese por Maurício e Alaor da Costa.

O filme ainda advoga que cabe ao artista intelectualizado o papel de recuperar a cultura produzida pelo povo para evitar o seu processo de desaparecimento ou a sua deturpação. Esse artista deveria retrabalhar as formas culturais populares para devolvê-las ao povo. O papel do artista consciente, portanto, não é nos salões, ao lado dos seus pares, mas nas ruas e nos morros, de forma a captar as manifestações culturais ali produzidas. Moacyr só compreende isso após a morte de Espírito, quando boa parte das suas músicas estava destinada a se perder. Note-se ser possível ainda inferir do filme que, no caso de o artista intelectualizado cumprir adequadamente o seu papel, a indústria cultural tenderia 
a funcionar em prol da cultura popular. Afinal, se Moacyr houvesse feito a partitura da música a tempo para Espírito, Ângela Maria a teria gravado. De fato, a estrutura da indústria cultural nunca é interrogada a fundo: ela aparece no filme como pura transparência, como um meio de comunicação sem necessidades próprias de retrabalhar os produtos que difunde. Em parte talvez essa perspectiva decorra do fato de que a indústria cultural ainda fosse embrionária no Brasil dos anos $195^{\circ}$.

Afigura-se de fundamental importância perceber que Rio, zona Norte já anuncia todo o programa do Cinema Novo nos seus primeiros anos, indicando o artista intelectualizado como demiurgo da cultura popular e sem o qual ela está destinada a sumir ou corromper-se. A posição ambígua em relação à indústria cultural também já está prenunciada. No caso de Rio, zona Norte, a função do artista intelectualizado está ligada ao trabalho na indústria cultural, de maneira a fazer com que ela funcionasse como divulgadora da "verdadeira" cultura popular.

Em relação especificamente à representação do afrobrasileiro, embora haja grande positividade na figura do personagem de Grande Otelo e apesar de o samba constituir-se no filme como o cerne da cultura brasileira, toda a questão racial acaba recoberta pela questão nacional. Note-se que Moacyr é branco e, apesar de paternalista, tem total respeito e consideração pela obra de Espírito. O erro de Moacyr foi não ter agido a tempo, afirma Rio, zona Norte, ou seja, não ter trabalhado para que aquelas músicas tivessem registro ou fossem recriadas a partir de um diálogo com a cultura de elite. A rigor, Rio, zona Norte não chega a discutir o problema racial no Brasil, já que tudo se resume à necessidade de cristalização de uma cultura nacional com base no que o filme entende como sendo a cultura popular.

\section{Orfeu}

Egresso do Cinema Novo, Carlos Diegues foi uma das figuras-chave no processo de rearticulação política da corporação cinematográfica ao longo dos anos 1990. Essa rearticulação logrou conseguir o estabelecimento de novas formas para o financiamento público para a produção de longas-metragens no país, pois, com a crise da Embrafilme e o seu fechamento em 1990, por ato do presidente Fernando Collor de Mello, a produção havia entrado em colapso. Somente a partir da 


\footnotetext{
5. O artigo terceiro da Lei 8685/1993, mais conhecida como a Lei do Audiovisual, permite que as empresas que exploram comercialmente produtos audiovisuais estrangeiros no Brasil utilizem até $70 \%$ do imposto de renda devido na coprodução de obras cinematográficas brasileiras.
}

Lei do Audiovisual, editada em 1993, já sob a presidência de Itamar Franco, a atividade lentamente se recuperou. Se nesse ano, foram lançados comercialmente apenas quatro longas-metragens brasileiros; em 1994, o número se ampliou para sete, chegando aos 26 filmes em 1998 e a 25 em 1999 (Gatti, 2007, p. 111).

Ademais, no final da década de 1990, novos parceiros começaram a se aproximar do cinema, como as Organizações Globo, por meio do seu braço para a atividade, a Globo Filmes, criada em 1998 (Butcher, 2006, p. 70). Orfeu foi um dos primeiros filmes coproduzidos pela Globo, tendo ainda sido distribuído pela Warner, major que por meio do artigo terceiro da Lei do Audiovisual investiu também na produção. ${ }^{5}$

Uma das recorrências na obra de Carlos Diegues é o destaque aos personagens negros, muitas vezes ocupando lugar central. Neste sentido, é possível destacar Ganga Zumba (1964), A grande cidade (1966), Xica da Silva (1976), Quilombo (1984) e Orfeu. Outra recorrência é a televisão, pois, como aponta Melina Marson, Bye, bye, Brasil (1979) abordou "a importância e a abrangência da televisão no Brasil”; já Dias melhores virão (1989) "apresentou uma concepção de cinema mais integrada com a indústria audiovisual"; e Veja esta canção (1994) foi mesmo coproduzido pela TV Cultura (Marson, 2009, p. 61).

Orfeu é baseado em uma peça de Vinicius de Moraes intitulada Orfeu da Conceição, escrita nos anos 1940, mas que só foi levada ao palco pela primeira vez em 1956. Segundo Robert Stam:

\footnotetext{
Vinicius estava lendo [em 1942] a versão do século XVIII da história de Orfeu, escrita pelo italiano Calzabigi, versão que mais tarde seria transformada em música pelo alemão Christoph Willibald Gluck. Ela conta a história do famoso músico, cantor e poeta que cantava de modo tão sedutor que os animais selvagens ficavam mansos e cuja aventura mais célebre foi sua viagem ao Hades em busca de Eurídice, filha de Apolo (Stam, 2008, p. 249).
}

Foi sob essa inspiração que Vinicius de Moraes adaptou a história, que se passa originalmente na Grécia, para os morros cariocas.

É de notar ainda que a peça serviu de base para a produção cinematográfica franco-ítalo-brasileira Orfeu do carnaval (1959), dirigida pelo francês Marcel Camus e ganhadora da Palma de Ouro 
de melhor filme no Festival de Cannes e do Oscar de melhor filme estrangeiro, ambos em 1959. Orfeu do carnaval foi um grande sucesso internacional de público e, embora a maior parte dos principais cargos técnicos estivesse entregue a estrangeiros, o elenco foi quase todo composto por artistas brasileiros negros como Breno Mello e Léa Garcia. Para Robert Stam, Orfeu do carnaval faz a seguinte representação dos afrobrasileiros:

\begin{abstract}
Os negros do filme são esmagadoramente adoráveis, simpáticos e criativos em suas vidas cotidianas. Não são muito sérios, mas, afinal, por que deveriam sê-lo no carnaval? Por outro lado nos é dado a ver muito pouco do trabalho criativo que exige uma apresentação de escola de samba, e não vemos qualquer evidência do alto grau de organização necessário (costuma-se dizer que as escolas de samba são as instituições mais bem organizadas do Brasil). Tudo é apresentado como se fosse espontâneo, dando ao espectador europeu uma sensação de estar diante do despreocupado "outro" tropical, que representa uma vida mais gratificante (Stam, 2008, p. 260).
\end{abstract}

A recepção ao filme de Marcel Camus pelo crítico Alex Viany foi bem negativa. Em um texto dedicado a Orfeu do carnaval, o crítico afirma que a obra "perde-se num emaranhado de confusões culturais, dramáticas, melodramáticas, mitológicas e psicológicas", chegando a caracterizá-la como "um perigo" para o cinema brasileiro, pois o "enorme sucesso comercial pode bem marcar o início da exploração de nossos grandes temas - exoticamente - por cineastas estrangeiros" (Viany, 1959). Poucos anos depois, em sua obra fundamental, Revisão crítica do cinema brasileiro $^{6}$, Glauber Rocha defende a importância da atividade intelectual de Alex Viany, entre outros fatores, porque o crítico ataca "a investida de cineastas estrangeiros, apoiados por intelectuais brasileiros, tipo Camus e o fantasismo de Orfeu" (Rocha, 2003, p. 103). Não é difícil perceber nesse ponto a influência de Viany sobre os então jovens cineastas ligados ao Cinema Novo.

O filme de Carlos Diegues, lançado exatamente 40 anos depois da obra de Marcel Camus, responde a alguns dos problemas apontados por Robert Stam e Alex Viany, buscando retirar o perfume exótico no qual a película francesa está embebida. Ao mesmo tempo, é interessante notar que o diretor brasileiro escolheu filmar em
6. Revisão crítica do cinema brasileiro foi lançado originalmente em 1963 pela editora Civilização Brasileira. 
um momento-chave de rearticulação do cinema nacional - com o apoio da televisão e de uma major - uma história cuja primeira versão nas telas teve ampla circulação mundial e "iniciou milhões de não brasileiros na cultura brasileira, forjando na consciência internacional uma poderosa associação entre três conceitos correlacionados: brasilidade, negritude e carnaval" (Stam, 2008, p. 247-248).

Orfeu inicia-se com a imagem da lua e de um avião, que corta o quadro. A seguir, há uma bela cena de amor entre o personagem central (Tony Garrido) e sua namorada, Mira (Isabel Fillardis). Ainda de madrugada, crianças do morro onde eles moram chamam o rapaz para que Orfeu faça o sol nascer e, de fato, ao mesmo tempo em que ele canta, o amanhecer ocorre. Essa sequência já dá o tom geral do filme, um tanto indeciso entre uma proposta mais naturalista e o tom mítico - que surge da própria história de Orfeu. No avião, está Eurídice (Patrícia França), jovem vinda do Acre para o Rio de Janeiro. Eurídice irá para o mesmo morro onde reside Orfeu, pois ela tem uma tia lá.

Já pela manhã, o rapaz, que é um músico de sucesso, vai ser entrevistado pela televisão. Mas eis que a polícia invade o morro com truculência atrás de Lucinho (Murilo Benício), o chefe do tráfico no local. Tiros são disparados a esmo pelos homens comandados pelo sargento Pacheco (Stepan Nercesian), enquanto a equipe de TV grava os abusos da polícia. Em vez do morro quase paradisíaco da versão francesa, Carlos Diegues apresenta a questão da violência decorrente da guerra entre a polícia e o tráfico de drogas, violência esta que possui papel central no filme, conforme se poderá verificar.

Após a confusão, Eurídice aparece meio perdida no morro e conhece o garoto Maykoll (Silvio Guindane) e a mãe de Orfeu, dona Conceição (Zezé Motta). Ela leva a moça para casa e pede ao menino que encontre a parente de Eurídice, dona Carmem (Maria Ceiça). Eurídice conhece Orfeu, que imediatamente se interessa por ela - a princípio, ainda acordando, ele a vê por entre estrelas.

Pela noite, Carmem leva Eurídice à quadra da escola de samba Unidos da Carioca, onde veem um animado ensaio e reencontram Orfeu. Ele exerce uma espécie de liderança na escola, trabalhando muito na coordenação de todos os seus membros para que carros, fantasias e adereços estejam prontos - e aqui há outra grande diferença em relação ao filme de Marcel Camus, o qual, segundo Robert Stam, não entrava na questão da organização e do trabalho 
exigidos por uma escola de samba. Mira também aparece por lá e vemos Orfeu entre três dos seus amores - afinal, foi Carmem quem o iniciou sexualmente. Eurídice sai dali e revê Maykoll, descobrindo uma pintura mural feita pelo menino na parede de um casebre.

Orfeu encontra Lucinho e é a partir daí que se dão alguns dos diálogos fundamentais do filme, pois os dois se conhecem desde crianças e antigamente eram amigos. O músico diz para o traficante sair da favela, pois o sargento Pacheco avisou a Orfeu que quer matar o bandido, Lucinho retruca, afirmando que fora dali não teria nada para fazer e não se sujeitaria a "ser gari ou faxineiro". Lucinho também quer saber por que Orfeu não sai do morro, porque, afinal, ele tem dinheiro para tanto. O músico responde: "Porque eu quero que todo mundo veja que para se dar bem não precisa ser igual a você". Nesse momento, a romantização e mesmo a idealização do filme a respeito daquele meio social atinge o seu máximo, pois tudo parece se resumir a escolher o lado certo - a arte - e evitar o errado - o crime. O trabalho com a produção artística é encarado pelo filme como grande possibilidade para as pessoas pobres escaparem da miséria e da marginalidade, e, nesse sentido, o menino Maykoll representa tal encruzilhada, pois ele não sabe se segue os passos do admirado Orfeu ou se aceita os presentes de Lucinho. Essa suposição da produção cultural como saída para a miséria, visto que ela se apresentaria como um mercado de trabalho, é das ideias contemporâneas difundidas pela grande mídia e que o filme Orfeu expressa sem nenhuma problematização.

Orfeu vai para casa e começa a tocar uma música em homenagem a Eurídice. O ambiente do quarto do músico é significativo, pois reúne elementos da contemporaneidade, tais como o computador - que, enquanto Orfeu toca, já "tira” a partitura - ou o microfone de último tipo, com elementos da tradição, como a bandeira da escola de samba e um disco de Cartola em destaque na cenografia. Todos esses elementos se justapõem sem nenhum problema. A música do personagem Orfeu é produto das maravilhas das novas tecnologias, mediado pela compreensão da tradição cultural brasileira (que, portanto, se manteria viva nas práticas culturais da atualidade).

E, a seguir, a tradição surge novamente, por meio da cena em que Eurídice tem sua fantasia preparada por dona Conceição, pois, no mesmo ambiente, há uma televisão na qual entrevemos o trecho 
de um filme preto e branco com Grande Otelo dançando alegremente. A obra não é identificada em Orfeu, mas se trata de um trecho da chanchada Carnaval Atlântida (José Carlos Burle, 1952). Aqui, o filme de Carlos Diegues procura, de um lado, demonstrar que o povo possuiria interesse pelo cinema brasileiro; de outro, trata-se de ligar o cinema nacional à tradição da cultura popular - afinal, a chanchada tinha como um dos seus elementos mais importantes o samba.

Maykoll leva Eurídice até um "justiçamento" no alto do morro, executado por Lucinho diante de vários outros populares. Eurídice sai dali assustada com o assassinato e entra em confronto com Orfeu, pois este nada faria contra Lucinho. Orfeu resolve tomar uma atitude e intima o chefe do tráfico a sair da favela. Ela fica encantada com a atitude do músico, e eles se beijam nas escadarias do morro, sendo enquadrados pelo movimento circular da câmera. Orfeu carrega-a nos braços e eles acabam fazendo sexo na casa dele. Pela manhã, eles se falam ao telefone, pois Orfeu já está no Sambódromo para o grande dia do desfile. Ele promete, então, que no dia seguinte irão embora do morro, como ela quer.

No Sambódromo, desfila a Unidos da Carioca. Planos abertos destacam a beleza da escola. Nos planos mais fechados, encontramos os personagens Mira, Carmem, Conceição e, com mais destaque, Orfeu - que parece dominar tudo. O samba-enredo tem uma parte com ritmo de rap e foi composto por Orfeu. Na favela, pela televisão, Lucinho vê Orfeu. Eurídice também acompanha o desfile dessa forma e conclui que o amado nunca sairá do morro. Ela, então, resolve ficar ali com ele.

Eurídice sobe até o alto do morro vestindo uma fantasia. Lucinho - perturbado pelo uso de drogas - vai ao seu encontro, tenta beijá-la, ela foge, e ele, para assustá-la, atira para baixo, mas a bala resvala em uma pedra e a atinge. Terminado o desfile, Orfeu volta ao morro. Maykoll dá para ele, de presente, um quadro no qual o músico aparece com sua fantasia de Carnaval: o menino diz que, para fazer a pintura, "copiou da TV" o desfile da escola. É de observar o papel da televisão no contexto do filme: uma mídia a serviço da expressão da cultura popular e dos seus problemas. Se, de início, foi uma reportagem televisiva que denunciou a arbitrariedade da polícia, agora ela é o meio pelo qual muitas pessoas - inclusive a gente do próprio morro - têm acesso à cultura popular cristalizada no desfile da es- 
cola de samba. E esse papel da televisão retroalimenta a cultura do próprio povo. Afinal, Maykoll "copia” do aparelho para fazer a sua pintura. Curiosamente, ele não se inspira nos ensaios que ocorriam ali mesmo; afinal, assim, a televisão perderia parte da sua importância na trama e no discurso ideológico do filme.

Orfeu não encontra Eurídice. Pela manhã, acaba descobrindo que Lucinho sabe do paradeiro da moça. Ele vai até o esconderijo do traficante e este confessa que ela está morta. Orfeu, em um espelho, em vez do seu reflexo, vê a imagem de Eurídice, mas o espelho se parte em pedaços. Ele convence Lucinho a levá-lo até onde está o corpo de Eurídice. Os dois vão até o alto do morro, e lá Orfeu abraça o traficante, retira a arma dele e o mata - em mais uma situação que foge ao naturalismo, pois, quando ele abraça Lucinho, ainda é dia, e logo depois a noite se faz. Orfeu desce o despenhadeiro, e diante de muita sujeira e cadáveres de gente morta, encontra o corpo de Eurídice sobre os galhos de uma árvore. Ele não está decomposto; apenas um tanto lívido. A referência à mitologia, na qual Orfeu desce ao Hades para encontrar Eurídice, é mais forte aqui, pelo fato de a cenografia e a iluminação escaparem ao verossímil.

Orfeu canta para sua amada. Ele a leva nos braços, mas parece enlouquecido, achando que ela está viva. No meio de uma praça, Orfeu pousa o corpo de Eurídice. De um bar, Mira e Carmem, bêbadas, veem o antigo amante e são possuídas pelo ciúme. Mira pega uma estaca grande e ataca Orfeu, que cai morto ao lado da amada. Os membros da comunidade que estão ali choram a morte do músico. Um plano geral, que do alto enquadra a praça e o casal morto, desloca-se para um dos quadros de Maykoll e para a tela de um aparelho de TV. É anunciada a vitória da Unidos da Carioca e, na televisão, há imagens da escola desfilando. O filme termina com Orfeu e Eurídice com fantasias de Carnaval, à frente de uma escola de samba. Eles dançam e se beijam em câmera lenta, ao som de $S e$ todos fossem iguais a você, cantada por Caetano Veloso.

Nesse encerramento, há novamente a afirmação da positividade da mídia televisiva, pois o movimento da câmera e o modo como estão dispostos, lado a lado, o quadro pintado pelo menino e a tela do aparelho de TV parecem equivaler a essas duas expressões ligadas ao povo: uma saída diretamente dele; enquanto a outra difunde para todos o espetáculo produzido pelo povo. Nada é problematizado nessa relação do Carnaval com a mídia. 
E quanto ao discurso racial do filme? De um lado, deve-se louvar o fato de que a maior parte do elenco é de negros, incluindo quase todos os papéis principais - ainda uma raridade no universo audiovisual brasileiro. No entanto, o personagem Orfeu nunca "racializa" o seu discurso, e o fato de Lucinho ser branco acaba por fazer com que o filme repita o velho discurso de que não existe nenhum dilema racial no Brasil, mas tão somente um problema social que afeta negros, mulatos e brancos nas periferias das grandes cidades. Ou seja, apesar de produzido às portas do século XXI, o filme não tem a mínima atenção para com a especificidade da luta do negro no Brasil.

\section{Observações finais}

Afigura-se interessante fazer um paralelo entre Rio, zona Norte e Orfeu, ambos pontas do projeto nacional popular do cinema brasileiro, realizados por dois dos mais importantes diretores do Cinema Novo e tendo como personagens centrais o compositor popular negro morador dos morros cariocas.

O que nos anos 1950 era a denúncia da injustiça contra o artista popular, a tentativa então corajosa de apontar no samba o verdadeiro cerne da cultura brasileira e a investigação de formas de representação realistas sobre o povo brasileiro; já no final do século se tornou um discurso acrítico sobre o artista que vence na grande mídia, a aceitação como forma de expressão popular de estruturas artísticas totalmente enquadradas pela indústria cultural - como o sambaenredo - e a articulação de uma proposta estética mal resolvida na busca da representação do povo - expressa na mistura indefinida e confusa do tom naturalista com o mítico. Não são poucas as diferenças e talvez seja possível atribuí-las parcialmente ao fato de que ideologicamente o "nacional-popular" era uma promessa efetiva de libertação na época de Rio, zona Norte, enquanto hoje é apenas um discurso que justifica ideologicamente a ação da grande mídia televisiva no Brasil e de parte da produção cinematográfica.

Renato Ortiz, ao analisar a tradição do "nacional-popular" dos anos 1950, identifica que ela possuía forte acento político, e os seus ideólogos (intelectuais e artistas) buscavam, pela via da cultura popular, fazer com que o povo assumisse "uma consciência crítica dos 
problemas sociais" (Ortiz, 1994, p, 162). No entanto, com a afirmação da indústria cultural no Brasil, o "nacional-popular" modifica-se:

No caso da moderna sociedade brasileira, popular se reveste de um outro significado, e se identifica ao que é mais consumido, podendo-se inclusive estabelecer uma hierarquia de popularidade entre diversos produtos ofertados no mercado. Um disco, uma novela, uma peça de teatro serão considerados populares somente no caso de atingirem um grande público. Neste sentido se pode dizer que a lógica mercadológica despolitiza a discussão, pois se aceita o consumo como categoria última para se medir a relevância dos produtos culturais (Ortiz, 1994, p. 164).

A partir dessa análise, é possível pensar que o personagem central de Rio, zona Norte seria popular não somente pela sua origem de classe mas também pelo fato de que suas músicas expressariam a experiência popular e conduziriam seu público, principalmente o intelectual de classe média, a um conhecimento crítico sobre o Brasil. Já Orfeu seria popular pelo fato de que suas músicas são consumidas por todos, tanto na favela como pelo resto do país. Há, nesse, caso total harmonia entre produção artística, indústria cultural e público.

Rio, zona Norte já aponta para a importância do rádio na veiculação da produção cultural e constrói uma perspectiva segundo a qual a ação militante do artista intelectualizado seria essencial para que a música popular não se corrompesse, o que poderia ocorrer devido à ação de indivíduos sem escrúpulos, e não por qualquer relação mais própria da indústria cultural. Em Orfeu, a televisão encontra-se presente de forma bem articulada, pois fica evidenciado que a massificação das músicas do personagem ocorre por meio dessa mídia; ademais, não há a necessidade do intelectual para colaborar com o artista popular. Porém, apesar dos mais de 40 anos que separam as duas obras, Orfeu - o filme - ainda é caracterizado pela ausência de consciência sobre o caráter estrutural e estruturante da indústria cultural, pois Orfeu - o personagem - parece ter uma relação direta com a televisão, a qual retransmite a produção do músico e da sua comunidade, mas sem alterar sua significação cultural mais profunda. Tanto em Rio, zona Norte quanto em Orfeu, não há nenhum tipo de atenção para com os processos pelos quais um pro- 
duto artístico passa para ser difundido pela indústria cultural; tudo se passa como se o rádio ou a televisão apenas divulgassem de forma massiva as maravilhas criadas pela imaginação popular.

Quanto à questão da representação do afrodescendente, seria de assinalar um dado que já se faz presente no romance Jubiabá e nas películas de Nelson Pereira do Santos e Carlos Diegues. Tratase da persistência na representação da mulata como personagem totalmente negativa, estereótipo que na produção artística brasileira possui exemplos já tradicionais, como a Rita Baiana do romance $O$ cortiço, de Aluísio de Azevedo. A Rosenda Rosedá de Jubiabá tem ecos claros na Adelaide de Rio, zona Norte e na Mira de Orfeu, pois todas são belas, sexualmente bastante ativas e oportunistas.

Ademais, os dois filmes compartilham o total apagamento de qualquer discurso racial e nisso ambos são praticamente idênticos, pois o personagem negro é antes o símbolo de todo o povo brasileiro; daí não poder possuir nenhuma especificidade da luta ou pelo menos da história dos afrobrasileiros. O discurso sobre a questão racial tem de ser reprimido porque ele quebra a lógica do "nacional-popular", no qual todos os problemas - em termos culturais, sociais, econômicos etc. - decorrem da ação dos estrangeiros ou dos representantes nacionais dos seus interesses.

Se no romance Jubiabá a percepção da opressão racial acabava sendo substituída e suprimida pela consciência politizante do personagem Antônio Balduíno, nos filmes analisados, esse processo nem existe, já que os personagens Espírito da Luz Soares e Orfeu já surgem como símbolos do povo brasileiro. 


\section{Bibliografia}

AMADO, J. Jubiabá. Rio de Janeiro: Record, 1984.

BAZIN, A. O cinema: ensaios. São Paulo: Brasiliense, 1991.

BOSI, A. História concisa da literatura brasileira. São Paulo:

Cultrix, 1994.

BROOKSHAW, D. Raça E cor na literatura brasileira. Porto

Alegre: Mercado Aberto, 1983.

BUTCHER, P. A dona da história: origens da Globo Filmes e seu impacto no audiovisual brasileiro. Dissertação (mestrado).

Universidade Federal do Rio de Janeiro, Rio de Janeiro, 2006.

FABRIS, M. Nelson Pereira dos Santos: um olhar neo-realista? São

Paulo: Edusp/Fapesp, 1994.

GALVÃO, M. R. "O desenvolvimento das idéias sobre Cinema Independente”. In: Cadernos da Cinemateca. São Paulo, n. 4,1980 .

GATTI, A. "O mercado cinematográfico brasileiro: uma situação global?” In: MELEIRO, A (Org.). Cinema no mundo: indústria, política e mercado - América Latina. São Paulo: Escrituras Editora, 2007.

MARSON, M. I. Cinema e políticas de Estado da Embrafilme à Ancine. São Paulo: Escrituras Editora, 2009.

ORTIZ, R. A moderna tradição brasileira: cultura brasileira e indústria cultural. São Paulo: Brasiliense, 1994.

ROCHA, G. Revisão crítica do cinema brasileiro. São Paulo: Cosac Naify, 2003.

SANTOS, N. P. dos. “Caiçara: Negação do cinema brasileiro”. In: Fundamentos. São Paulo, v. III, n. 17, jan. 1951.

SIMIS, A. Estado e cinema no Brasil. São Paulo: Annablume/ Fapesp, 1996.

STAM, R. Multiculturalismo tropical: uma história comparativa da raça na cultura e no cinema brasileiro. São Paulo: Edusp, 2008.

VIANY, A. "Os perigos de Orfeu do carnaval”. In: Leitura. Rio de Janeiro, v. XVIII, n. 30, dez. 1959.

XAVIER, I. O cinema brasileiro moderno. São Paulo: Paz e Terra, 2001. 


\section{Filmografia}

Orfeu. Brasil, 1999. Longa-metragem, cor, 110 min. Companhia produtora: Rio Vermelho. Direção: Carlos Diegues. Roteiro: Carlos Diegues. Fotografia: Affonso Beato. Montagem: Sérgio Mekler. Som: Tom Paul. Música: Caetano Veloso. Produção: Renata de Almeida Magalhães e Paula Lavigne. Elenco: Toni Garrido, Patrícia França, Murilo Benício, Zezé Motta, Isabel Fillardis, Maria Ceiça, Stepan Nercesian e Silvio Guindane.

Rio, zona Norte. Brasil, 1957. Longa-metragem, PB, 82 min. Companhia produtora: Nelson Pereira dos Santos Produções Cinematográficas. Direção: Nelson Pereira dos Santos. Roteiro: Nelson Pereira dos Santos. Fotografia: Hélio Silva. Montagem: Mario del Rio. Som: Silvio Rabelo. Música: Alexandre Gnatalli e Radamés Gnatalli. Produção: Nelson Pereira dos Santos. Elenco: Grande Otelo, Jece Valadão, Paulo Goulart, Maria Petar, Malu, Haroldo de Oliveira e Vargas Jr. 